\title{
Pig Slurry Concentration by Vacuum Evaporation: Influence of Previous Mesophilic Anaerobic Digestion Process
}

\author{
August Bonmatí and Xavier Flotats \\ Laboratory of Environmental Engineering, Department of Environment and Soil Science, University \\ of Lleida, Spain
}

\begin{abstract}
Water can be removed from pig slurry by evaporation, through the application of wasted heat from a power plant or from other processes. Apart from obtaining a concentrate with an obviously higher nutrient concentration than the original slurry, another objective of water removal is to obtain water as condensate, which could be reused. The objective of this work was to study the vacuum evaporation of pig slurry liquid fraction and to evaluate condensate composition as a function of both $\mathrm{pH}(4$, 5 , and 6) and pig slurry type (fresh slurry and anaerobically digested slurry). Batch experiments showed that condensate characteristics, total ammonia nitrogen $\left(\mathrm{NH}_{3}-\right.$ $\mathrm{N})$, volatile fatty acids (VFA), and chemical oxygen demand were strongly dependent on initial slurry $\mathrm{pH}$. In addition to producing part of the required thermal energy, previous anaerobic digestion presented several other clear advantages. The consumption of VFA and other volatile organic compounds during anaerobic digestion reduced the volatilization of organic matter in the evaporation treatment and, consequently, provided a higher quality condensate.
\end{abstract}

\section{INTRODUCTION}

Since antiquity, farmers have used animal excrement as a source of minerals and organic matter for crop production. However, in recent years, the huge growth of

\section{IMPLICATIONS}

Concentration of pig slurry by water evaporation is sensible in a scenario where nutrients are to be recovered and waste transport is a limiting factor. It is necessary to avoid atmospheric emissions and contaminated condensates, to be reused. Present work indicates that previous anaerobic digestion treatment significantly decreases the condensate contamination by organic matter, providing part of the required energy. In the described scenario, regulations must ensure that vacuum evaporation is applied for preventing atmospheric emissions, and previous anaerobic digestion treatment is used to save energy and to obtain high quality condensates. livestock farming has resulted in a number of negative side effects associated with the use of livestock waste. Several of these have been associated with major increases in meat production in certain areas. The importation of feed ingredients from other countries or regions has resulted in surpluses of animal manure, with soils receiving overdoses of minerals such as phosphorus and nitrogen in certain regions. ${ }^{1}$

Nutrient redistribution between areas with surpluses and those with shortages is limited by transportation and spreading costs, caused by the high water content of the slurries and their relatively low nutrients concentration. Treatments that aim to reduce volume economically favor redistribution, and some of these may also generate mineral fertilizers from organic residues. ${ }^{2}$

Pig slurry is one of the most problematic types of livestock waste. The large volume generated, its high polluting potential, and its high water content often limit its correct management. Water can be removed from slurry by evaporation, through the application of wasted heat from other processes. This water can be recovered by condensation. In addition to obtaining a concentrate with a lower water content and higher nutrient concentration than the original slurry, another objective is to obtain water as condensate, which could be reused. The existence of an inexpensive source of heat is the main limitation for the practical application of this process. The Spanish Royal Decree 2818/98 on Energy, Cogeneration and Wastes establishes a subsidy to the electrical energy generated by cogeneration if thermal energy is used for reducing the volume of pig slurry, sewage sludge, or other organic waste.

Evaporation treatment of slurry can lead to severe atmospheric pollution. Slurry contains volatile compounds that are emitted when temperature is raised. In this sense, vacuum evaporation offers several advantages: as it occurs in a closed system, the exhaust gases can be easily treated, and the low treatment temperatures, resulting from the low treatment pressures, reduce the emission of volatile compounds. 
The main volatile components of slurry are ammonia nitrogen $\left(\mathrm{NH}_{3}-\mathrm{N}\right)$ and un-ionized volatile fatty acids (VFA). By adjusting the $\mathrm{pH}$, these can be transformed into non-volatile ions (see Figure 1). A pH less than 6 is needed for an almost complete ionization of total ammonia nitrogen $\left(\mathrm{NH}_{3}-\mathrm{N}_{\mathrm{T}}\right)$; on the other hand, reducing the $\mathrm{pH}$ increases the un-ionized VFA fraction (Figure 1). Theoretical studies ${ }^{5}$ showed that, at $\mathrm{pH}=4,1 \%$ of $\mathrm{NH}_{3}-\mathrm{N}_{\mathrm{T}}$ and $75 \%$ of acetic acid are transferred to the condensate, and that at $\mathrm{pH}=10,93 \%$ of ammonia and $1 \%$ of acetic acid are transferred to the condensate. It must be noted then that, if a liquid has a high $\mathrm{NH}_{3}-\mathrm{N}_{\mathrm{T}}$ and VFA content (i.e., pig slurry), it is not possible to prevent the volatilization of both components by adjusting its $\mathrm{pH}$ to a unique given value. A two-stage evaporation process or a previous treatment is necessary to prevent their emission during evaporation.

Anaerobic digestion treatment before evaporation could present several advantages: (1) to provide part of the energy needed, and (2) to remove volatile organic matter and, consequently, to obtain evaporation condensates free, or almost free, of organic matter, avoiding a two-stage evaporation process. This assumption must be tested for pig slurry.

Limited information has been found on the evaporation of liquid wastes. Vitolo et al. ${ }^{6}$ studied the evaporation of waste obtained from olive milling (vegetation water) with the aim of overcoming the limited biodegradability of this kind of waste. Nilsson and Strand ${ }^{7}$ studied the combination of evaporation and anaerobic digestion of wastewater from a wood pulp factory. McKeough and Fagernäs ${ }^{8}$ studied the evaporation of paper-mill process wastewater. Landfill leachate is one of the liquid wastes that has received the greatest attention, ${ }^{5,9}$ and the studies performed have focused on obtaining condensates fitting acceptable discharge limits. In general, those wastes have a lower organic matter concentration and fewer suspended solids than pig slurry. No information has been found about the evaporation of the pig slurry liquid fraction.

The aim of the present investigation was to study the vacuum evaporation of pig slurry and to evaluate the composition of the condensate as a function of $\mathrm{pH}$ and pig slurry type (fresh or anaerobically digested slurry). Special attention was paid to the two main volatile components of pig slurry $\left(\mathrm{NH}_{3}-\mathrm{N}_{\mathrm{T}}\right.$ and VFA), to the chemical oxygen demand (COD), and to the final nutrients composition (N, P, and $\mathrm{K}$ ) of the obtained concentrate.

\section{METHODS}

\section{Raw Material}

Two types of pig slurry liquid fraction were used: fresh slurry from a pig farm which had been filtered through a $200 \mu \mathrm{m}$ sieve, and the liquid fraction from a centrifuge fed with the effluent of a full-scale pig slurry mesophilic anaerobic reactor (Table 1).

\section{Experimental Design}

Because $\mathrm{pH}$ adjustment process is the necessary previous step to evaporation, it was studied for the two pig slurry types. The $\mathrm{pH}$ was modified with $\mathrm{H}_{2} \mathrm{SO}_{4}(10 \%)$ and the titration curves were compared. Then, two different evaporation tests were performed: batch evaporation tests and semi-continuous evaporation tests.

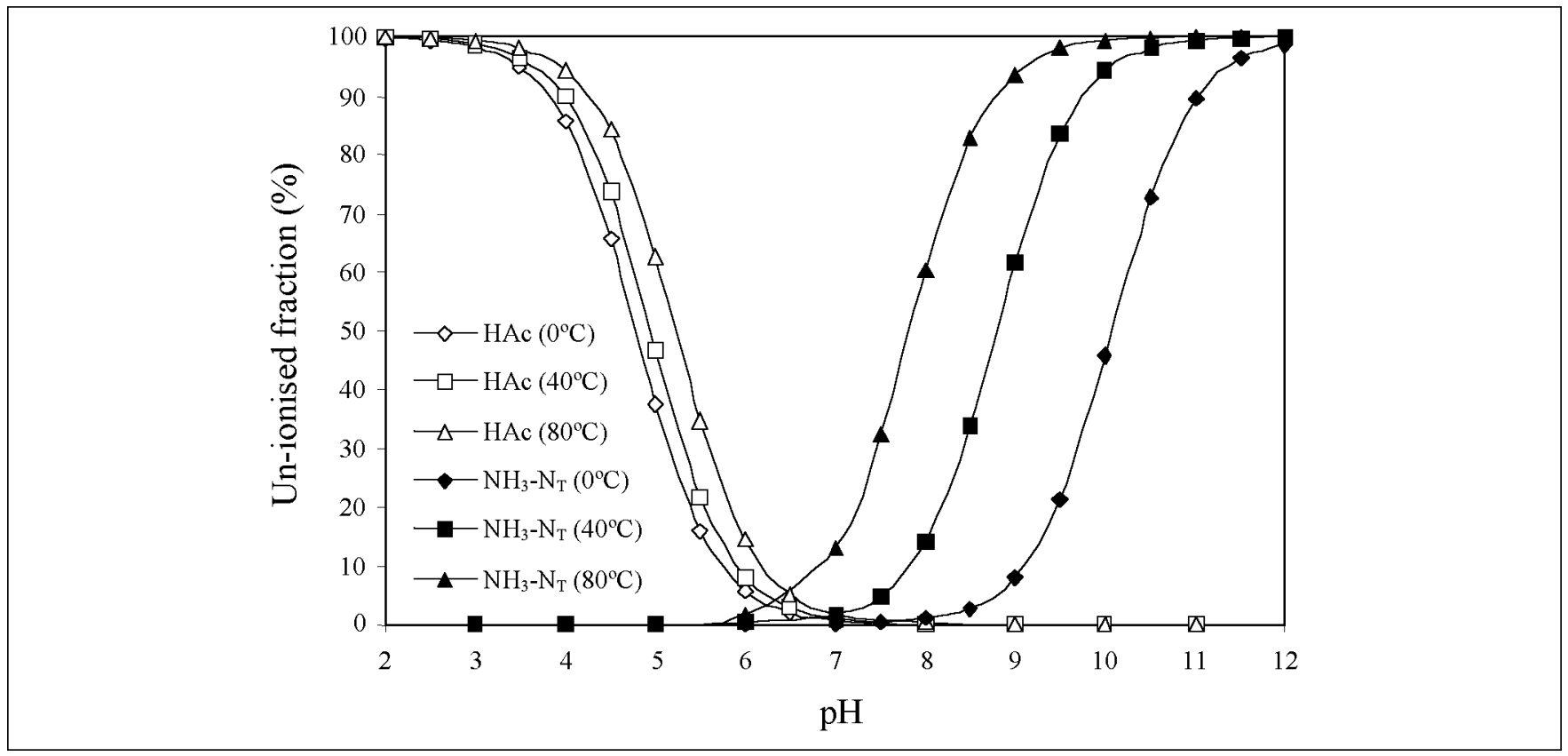

Figure 1. $\mathrm{NH}_{3}-\mathrm{N}_{\mathrm{T}}$ and un-ionized acetic acid $(\mathrm{HAC})$ fraction as a function of $\mathrm{pH}$ at different temperatures. Data from Perry ${ }^{3}$ and Lide. ${ }^{4}$ 
Batch Evaporation Tests. Six treatments were compared: two types of pig slurry (fresh slurry liquid fraction, and digested slurry liquid fraction), and three initial pHs (4, 5, and 6), with three replications. The evaporator, a 250-mL glass vial, was filled with $175 \mathrm{~mL}$ of slurry. Pressure of the vacuum pump was set at $6.7( \pm 0.1) \mathrm{kPa}$, and temperature of the batch was gradually increased to $40( \pm 1)$ ${ }^{\circ} \mathrm{C}$, to prevent foaming and contamination of the condensate. Water at or below $4{ }^{\circ} \mathrm{C}$ was used as a cooling fluid in the condenser. The condensates were characterized during evaporation following collection of the condensate as a sequence of different volumes $(45-50 \mathrm{~mL}$ each sample).

The global concentration of each one of the components studied was calculated applying eq 1 , to analyze the effect of $\mathrm{pH}$ on condensate characteristics,

$$
C c_{\mathrm{g}}=\frac{\sum\left(C c_{\mathrm{j}} \times V c_{\mathrm{j}}\right)}{\sum V c_{\mathrm{j}}}, j=1,2,3
$$

where $C c_{\mathrm{g}}(\mathrm{mg} / \mathrm{L})$ is the global concentration of a given component $\left(\mathrm{NH}_{3}-\mathrm{N}_{\mathrm{T}}\right.$, VFA, or COD) in the condensate; $\mathrm{Cc}$ $(\mathrm{mg} / \mathrm{L})$ is the concentration of a given component in the different condensate samples; $V c(\mathrm{~L})$ is the volume of the different condensate samples, and $j$ refers to each specific sample.

The percent $\mathrm{NH}_{3}-\mathrm{N}_{\mathrm{T}}$, VFA, or COD transferred to the condensate were used to compare the two slurry types. The percent transferred was calculated by eq 2

$$
\% \text { Transferred }=\frac{V c_{\mathrm{g}} \times C c_{\mathrm{g}}}{Q i \times C s_{\mathrm{i}}} \times 100
$$

where $Q_{\mathrm{i}}(\mathrm{kg})$ is the total amount of slurry treated; $C s_{\mathrm{i}}$ $(\mathrm{g} / \mathrm{kg})$ is the concentration of a given component $\left(\mathrm{NH}_{3}\right.$ $\mathrm{N}_{\mathrm{T}}$, VFA, or COD) in the original slurry; $V c_{\mathrm{g}}(\mathrm{L})$ is the total volume of the condensate; and $C c_{\mathrm{g}}(\mathrm{g} / \mathrm{L})$ is the global concentration of the component in the condensate.

The concentrate was analyzed at the end of the experiment. The percentages of Total Kjeldahl Nitrogen (TKN), $\mathrm{P}$, and $\mathrm{K}$ retained in the concentrate were calculated as follows:

$$
\% \text { Fixed }=\frac{Q_{\mathrm{f}} \times C s_{\mathrm{f}}}{Q_{\mathrm{i}} \times C s_{\mathrm{i}}} \times 100
$$

where $Q_{\mathrm{i}}(\mathrm{kg})$ is the total amount of slurry treated; $C s_{\mathrm{i}}$ $(\mathrm{g} / \mathrm{kg})$ is the concentration of the component $(\mathrm{P}, \mathrm{K}$, or $\mathrm{TKN})$ in the slurry; $Q_{\mathrm{f}}(\mathrm{kg})$ is the weight of concentrate; and $\mathrm{Cs}_{\mathrm{f}}(\mathrm{g} / \mathrm{kg})$ is the concentration of the component in the concentrate.

Semi-Continuous Evaporation Tests. A semi-continuous lab-scale evaporator system was designed and constructed (Figure 2), to study the behavior of the two slurry types in a steady-state approach regime. The evaporator used was a tightly closed 2-L glass vessel. The evaporator was heated with hot water from a thermostatic bath, which circulated through a water jacket surrounding the evaporator. Water was pumped with a peristaltic pump controlled by a temperature probe placed inside the evaporator. The content of the evaporator was continuously mixed with a stirring blade. The blade was made of a soft material that slightly scrubbed the evaporator wall to prevent scaling. As in the batch experimental setup, water at or below $4{ }^{\circ} \mathrm{C}$ was used in the condenser.

Samples were taken periodically at three different points, when the condensate volume reached $150 \pm 20$ $\mathrm{mL}$. Two sampling devices were designed for extracting the condensate and the concentrate (4 and 5 in Figure 2). Both sample devices consisted of a glass tube with two valves. A three-way valve placed at the top of the sampling device allowed sample extraction without disturbing the vacuum evaporation system. Samples of the 


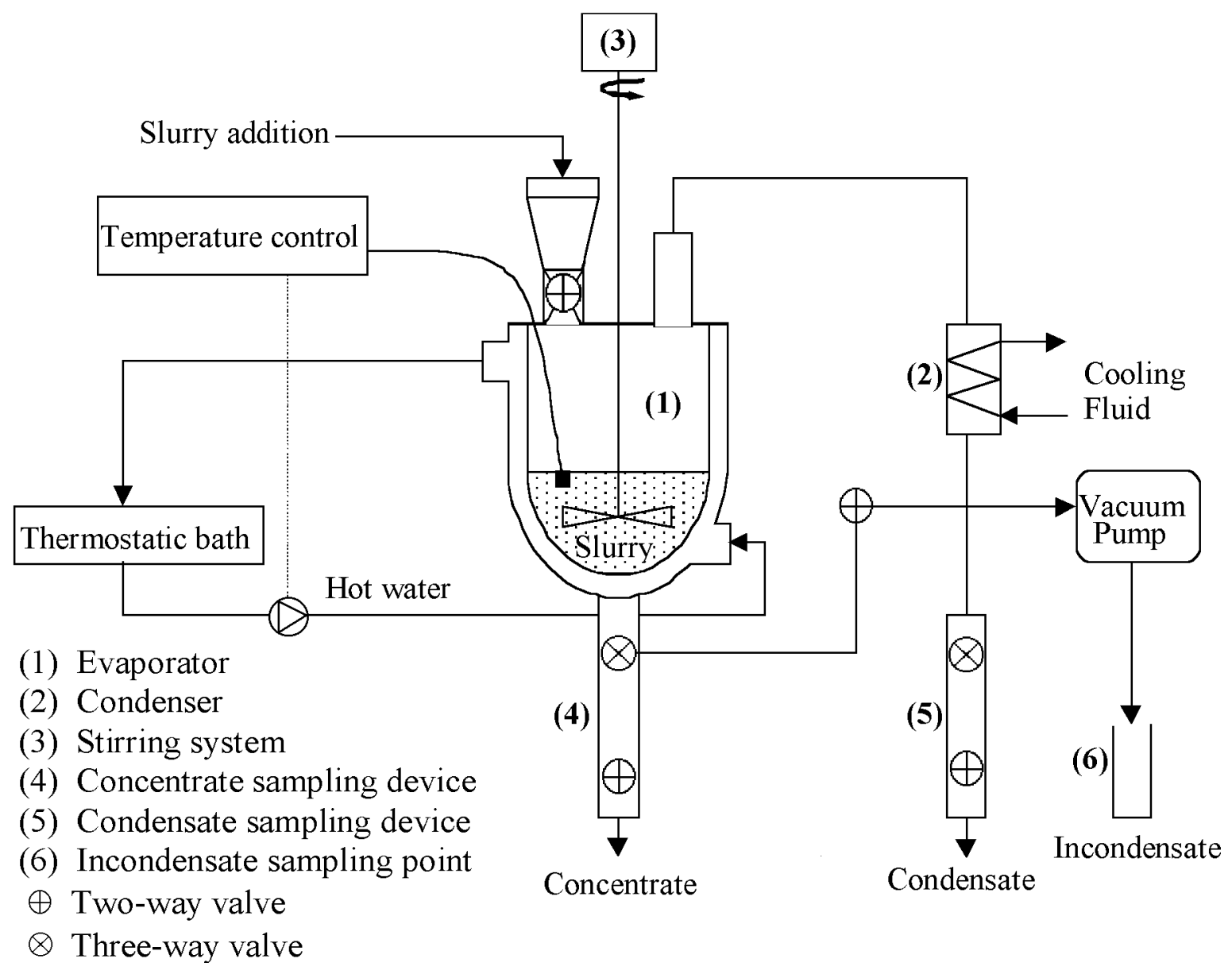

Figure 2. Experimental setup for the semi-continuous evaporation tests.

non-condensed vapors, called incondensates, were recovered after the vacuum pump (6 in Figure 2), in the tube conducting vapors outside the laboratory (condensation at room temperature and atmospheric pressure). The slurry was manually fed into the test device using a funnel.

Pressure was set at $13.3 \pm 0.3 \mathrm{kPa}$, temperature was $55 \pm 4{ }^{\circ} \mathrm{C}$, and the initial $\mathrm{pH}$ of the slurry was adjusted to 5 with $\mathrm{H}_{2} \mathrm{SO}_{4}$. The total solid (TS) concentration of the concentrate was set between 200 and $250 \mathrm{~g} / \mathrm{kg}$.

One limitation of the evaporators is that they only work with fluids. This constitutes a limitation to the final achievable concentration: slurry cannot be converted into a completely dry product, and a further drying process is necessary to increase the dry matter concentration. Water exists in four states in a complex water matrix: free water, capillary-held water, surface water, and chemically bound water. ${ }^{10,11}$ Free water is defined as the water removed during the constant drying-rate period. The final TS concentration achieved by removing this water fraction varies from waste to waste, and it is estimated to be between 200 and $250 \mathrm{~g} / \mathrm{kg}$ for livestock wastes. ${ }^{12}$
The semi-continuous experiments were divided into two periods: an initial transitory period followed by a steady-state period. During the transitory period, large volumes of slurry were added discontinuously until a volume of concentrate $(120-130 \mathrm{~mL})$ with a TS concentration between 200 and $250 \mathrm{~g} / \mathrm{kg}$ was obtained. Total slurry addition was $1.85 \mathrm{~L}$ in the fresh slurry experiment and $3.75 \mathrm{~L}$ in the digested slurry experiment. This relatively large difference was caused by the lower initial TS concentration of the digested slurry with respect to the fresh slurry. A longer treatment time therefore was required for the digested slurry. During the steady-state period, volumes of $50 \mathrm{~mL}$ of slurry were added every $30 \mathrm{~min}$. Before the concentrate was extracted, slurry addition was stopped until the mass balance indicated that the concentrate had reached the desired TS concentration.

\section{Analytical Methods}

Total Kjekdahl-N (TKN), total ammonia nitrogen $\left(\mathrm{NH}_{3}-\mathrm{N}_{\mathrm{T}}=\mathrm{NH}_{3}-\mathrm{N}+\mathrm{NH}_{4}{ }^{+}-\mathrm{N}\right), \mathrm{pH}$, total solids (TS), 
volatile solids (VS), total suspended solids (TSS), volatile suspended solids (VSS), soluble total solids (STS), and COD were all analyzed by standard methods. ${ }^{13}$ Partial and total alkalinity (PALK, TALK) were analyzed by titration with $\mathrm{HCl}$ to $\mathrm{pH} 5.75$ and 4.3, respectively. ${ }^{14}$ The alkalinity ratio (RALK) was calculated according to Iza. ${ }^{14}$ Total phosphorous (P) was analyzed by the colorimetric method (coloring reaction with ammonia molybdate vanadate), and total potassium (K) was determined by means of a flame atomic absorption spectrometer (FAAS). Volatile fatty acids were measured using a ThermoInstruments Trace 2000 gas chromatograph, with an FFAP capillary column $(0.25 \mathrm{~mm}$ ID and $30 \mathrm{~m}$ long) and a flame ionization detector. He was used as the carrier gas with a flow rate of $1 \mathrm{~mL} / \mathrm{min}$.

\section{Statistical Analysis}

Statistical analysis was performed using SAS software. ${ }^{15} \mathrm{~A}$ one-way ANOVA test was carried out. When this analysis indicated significant differences, a means separation test was used, applying the Student-Newman-Keuls method, with a significance level of $\alpha=0.05$.

\section{RESULTS AND DISCUSSION}

\section{pH Adjustment of the Raw Material}

The volume of acid used to reach pH 5 and 4 differed widely between the two slurries. The fresh slurry consumed $100 \mathrm{~mL} \mathrm{H}_{2} \mathrm{SO}_{4} / \mathrm{L}(\mathrm{pH}=5)$ and $137 \mathrm{~mL} \mathrm{H}_{2} \mathrm{SO}_{4} / \mathrm{L}$ $(\mathrm{pH}=4)$, while the digested slurry needed $64 \mathrm{~mL}$ $\mathrm{H}_{2} \mathrm{SO}_{4} / \mathrm{L}(\mathrm{pH}=5)$ and $67 \mathrm{~mL} \mathrm{H}_{2} \mathrm{SO}_{4} / \mathrm{L}(\mathrm{pH}=4)$. This was in accordance with the higher TALK of the fresh slurry (Table 1). However, the acid volume required to reach $\mathrm{pH}=6$ was similar for both slurries, $64 \mathrm{~mL}$ $\mathrm{H}_{2} \mathrm{SO}_{4} / \mathrm{L}$ for fresh slurry and $57 \mathrm{~mL} \mathrm{H}_{2} \mathrm{SO}_{4} / \mathrm{L}$ for digested slurry (Figure 3a).
Carbonate alkalinity is the major component of the buffer capacity. Other contributors to alkalinity are VFA, phosphates, $\mathrm{NH}_{3}-\mathrm{N}$, and some other natural components. Eighty percent of the bicarbonate alkalinity, but only approximately $20 \%$ of the VFA alkalinity, is determined through titration to an endpoint of 5.75 (PALK), while an endpoint pH of 4.3 (TALK) assures that $99 \%$ of the bicarbonate alkalinity is measured, and more than $50 \%$ of the VFA alkalinity also is expressed.16,17 The similar PALK of the two slurries, the high amount of VFA in the fresh slurry, and the practical absence of VFA in the digested slurry (Table 1) all explain the different behavior of the titration curves of the two slurries (Figure 3a). However, the larger acid consumption in the fresh slurry than in the digested one cannot be generalized. Anaerobic digestion generates $\mathrm{CO}_{2}$, which leads to an increase in TALK and, therefore, a larger acid consumption is expected for its $\mathrm{pH}$ adjustment. The different slurry sources explain the higher TALK in the fresh slurry.

Otherwise, the behavior of the titration curves can be extrapolated. The alkalinity of an anaerobic effluent is mainly caused by carbonates, as VFA has been consumed through the anaerobic digestion process. Because the $\mathrm{pKa}$ of bicarbonate is $6.24^{17}$ a large amount of acid will be necessary to modify its $\mathrm{pH}$ to 6 , but further decrease in $\mathrm{pH}$ can be achieved with smaller acid additions. This fact is worthy of note because the $\mathrm{pH}$ control system in a continuous treatment plant might be set in different ways depending on the type of slurry involved and the $\mathrm{pH}$ desired.

Evolution of $\mathrm{pH}$ with time during the neutralization process is also interesting (Figure 3b). After an addition of sulfuric acid, $\mathrm{pH}$ dropped sharply, but a slight increase in $\mathrm{pH}$ was later seen. This can be explained by the solubilization of solids that occurred during neutralization, shown by the increase in STS

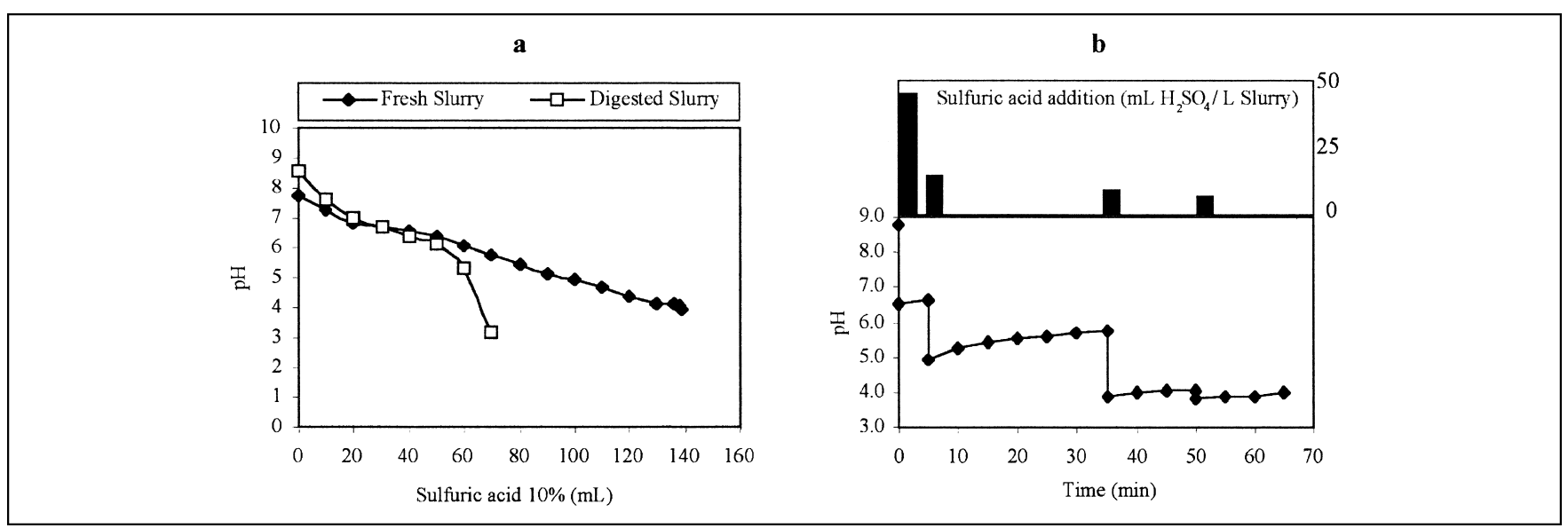

Figure 3. Titration curve for fresh pig slurry liquid fraction and digested slurry liquid fraction (a). pH evolution with time during the neutralization process (b). 


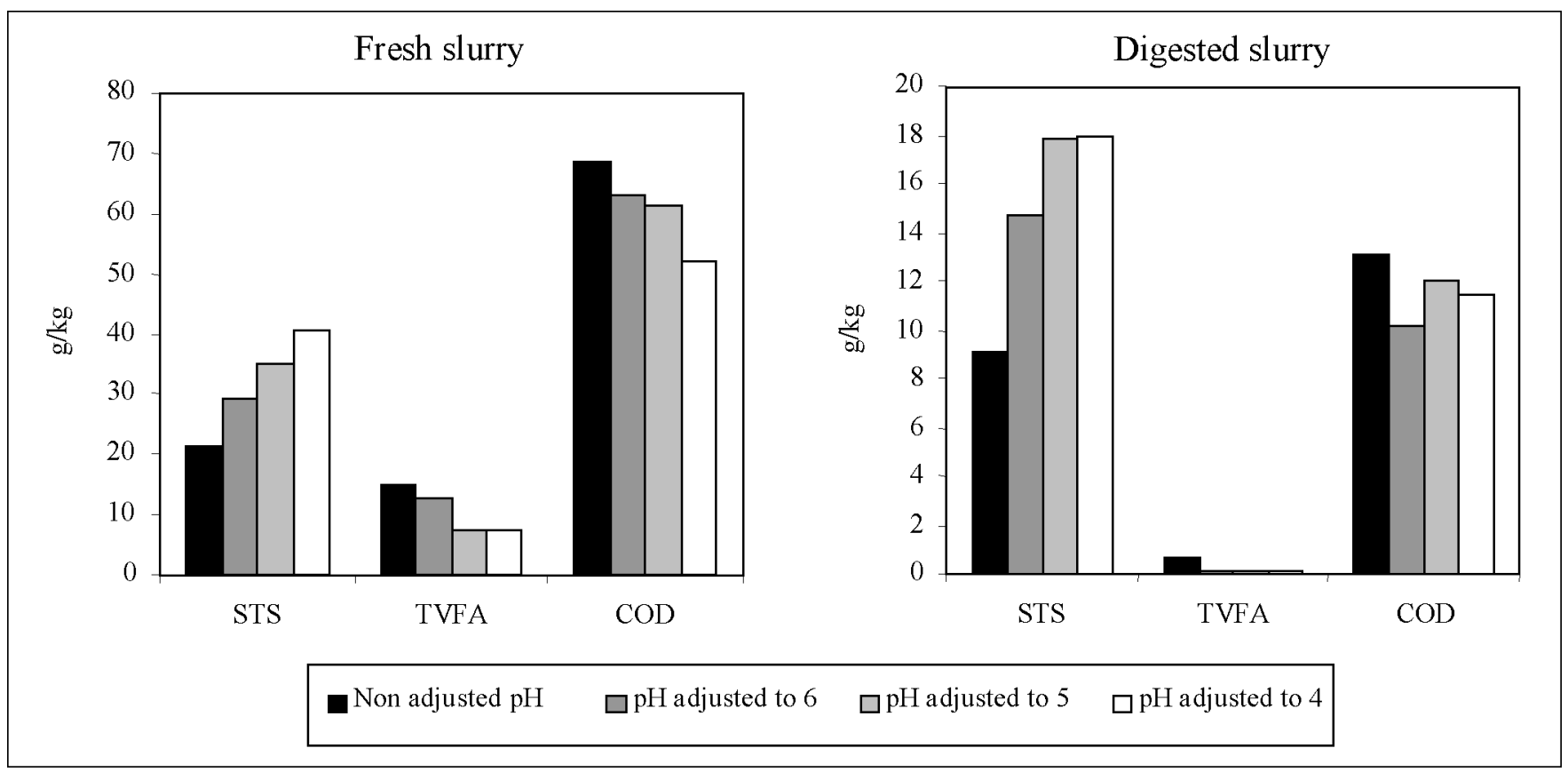

Figure 4. Effect of $\mathrm{pH}$ adjustment on soluble total solids (STS), TVFA, and COD on fresh slurry and digested slurry liquid fraction.

after $\mathrm{pH}$ modification, and the volatilization of VFA and the consequent overall decrease in COD concentration (Figure 4). This $\mathrm{pH}$ behavior indicated that a sensitive $\mathrm{pH}$ control system is needed for a correct control of $\mathrm{pH}$ without oscillations. ${ }^{18}$

\section{Batch Evaporation Tests}

Effect of the Initial Slurry pH on Condensate Characteristics. The global concentration of the condensate, calculated by applying eq 1, was used to study the effect of the initial $\mathrm{pH}$ on condensate characteristics. In the experiment with fresh slurry (Figure 5a), as expected, the higher the initial slurry $\mathrm{pH}$, the higher the total $\mathrm{NH}_{3}-\mathrm{N}$ concentration in the condensate. Even so, low total $\mathrm{NH}_{3}-\mathrm{N}$ concentrations were reported in all treatments. This showed that under these operational conditions $\left(\mathrm{T}=40^{\circ} \mathrm{C}\right.$ and $\left.\mathrm{P}=6.7 \mathrm{kPa}\right)$ and at the given $\mathrm{pH}$ values tested, total $\mathrm{NH}_{3}-\mathrm{N}$ was almost completely retained. The global TVFA concentration showed the opposite tendency: the lower the initial slurry $\mathrm{pH}$, the higher the VFA concentration in the condensate. Concentrations of TVFA of between 560 and $2300 \mathrm{mg} / \mathrm{L}$

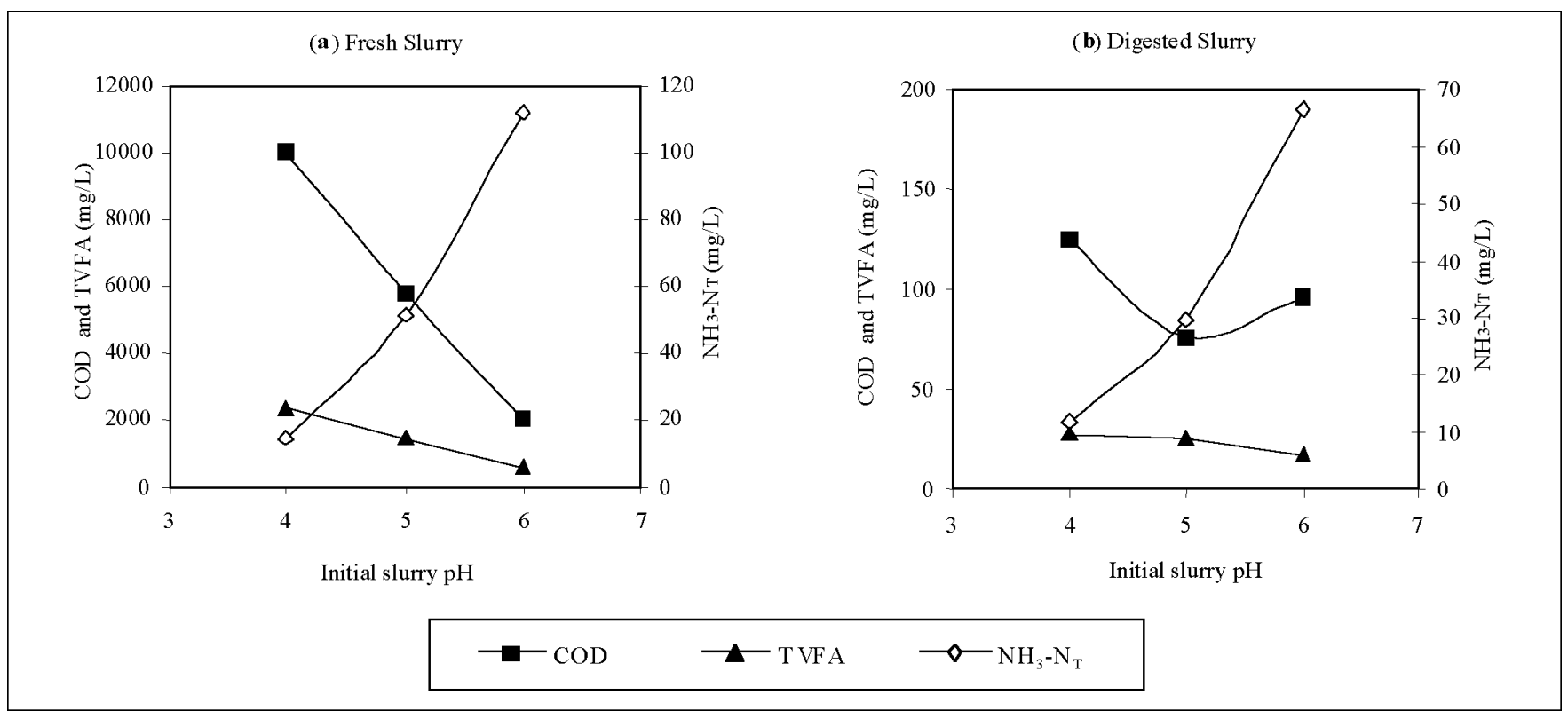

Figure 5. $\mathrm{NH}_{3}-\mathrm{N}_{\mathrm{T}}, \mathrm{COD}$, and TVFA concentration in the condensate as a function of the initial slurry pH: (a) experiments with fresh slurry, (b) experiments with digested slurry. 
were reported, showing that $\mathrm{pH}$ had a strong effect on the VFA concentration in the condensate. The un-ionized VFA fraction sharply increased within this range of $\mathrm{pH}$ values, as can be predicted by Figure 1 . Similarly, the global COD concentration in the condensate increased when $\mathrm{pH}$ decreased. The COD associated with TVFA represented $27 \%$ of the total COD in the fresh slurry.

As in experiments with fresh slurry, the total $\mathrm{NH}_{3}-\mathrm{N}$ and TVFA condensate concentration in the experiments with digested slurry presented the same pattern (Figure $5 b)$. On the other hand, no relation was found between COD and the initial pH of the slurry. This suggests that the volatile organic matter of the digested slurry was mainly composed by non-ionized compounds, which volatilization is not affected by $\mathrm{pH}$. The TVFA concentration of the digested slurry only represented $1.5 \%$ of the total COD.

It should also be noted that, at a given $\mathrm{pH}$, the total $\mathrm{NH}_{3}-\mathrm{N}$, COD, and VFA concentrations in the condensates from fresh slurry were much higher than those from digested slurry. This was in accordance with the higher $\mathrm{NH}_{3}-\mathrm{N}, \mathrm{COD}$, and VFA concentration in the fresh slurry than in the digested slurry (Table 1). To avoid the effect of the initial concentration on the results and to compare the behavior of the two slurry types, the percent mass transferred to the condensate (eq 2) was chosen for further evaluations (Figure 6).

Effect of Pig Slurry Type on Condensate Characteristics. The percent total $\mathrm{NH}_{3}-\mathrm{N}$ transferred in the experiments with digested slurry was larger than in those with fresh slurry for all the initial slurry pHs tested (Figure $6 a)$. In contrast, VFA \% transferred to the condensate was higher in experiments with fresh slurry than in those with digested slurry (Figure 6b). A pH increase of between 0.3 and 1.9 was observed depending on the initial $\mathrm{pH}$ and the type of slurry involved (Table 2 ). This was in accordance with the $\mathrm{pH}$ increase observed by Birchler et al., ${ }^{9}$ who reported a similar $\mathrm{pH}$

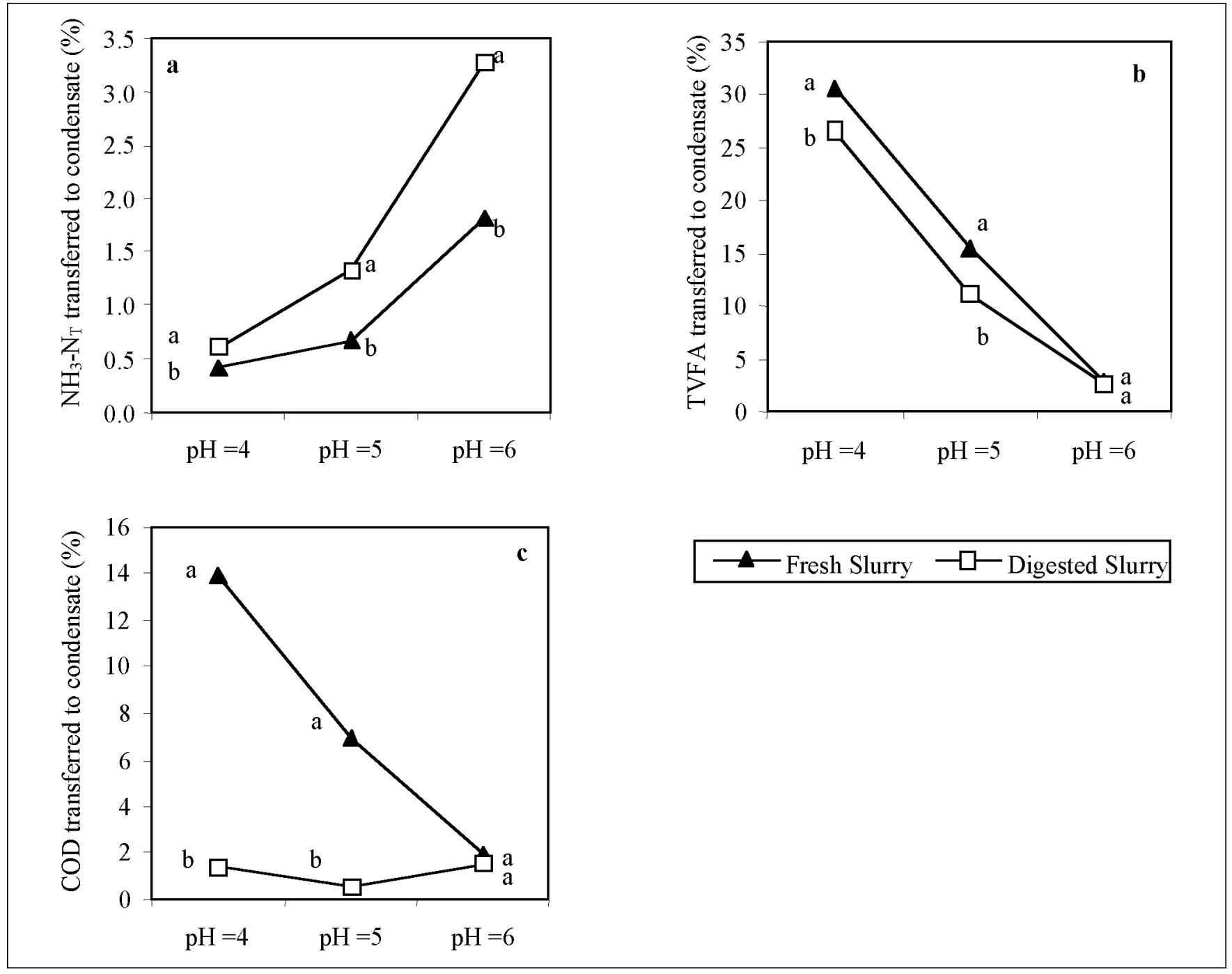

Figure 6. $\mathrm{NH}_{3}-\mathrm{N}_{\mathrm{T}}(\mathrm{a})$, TVFA (b) and COD (c)-transferred (\%) to the condensate in the batch evaporation experiments. With the same initial slurry pH, different letters show significant differences between means $(\alpha=0.05)$. 
Table 2. Characteristics (average of 3 repetitions) of the concentrate in batch evaporation tests (standard deviations are indicated within brackets).

\begin{tabular}{|c|c|c|c|c|c|c|}
\hline \multirow{2}{*}{$\begin{array}{l}\text { Initial } \\
\text { pH }\end{array}$} & \multicolumn{3}{|c|}{ Fresh Slurry Concentrate } & \multicolumn{3}{|c|}{ Digested Slurry Concentrate } \\
\hline & 6 & 5 & 4 & 6 & 5 & 4 \\
\hline pH & $6.3( \pm 0.04)$ & $5.3( \pm 0.04)$ & $4.6( \pm 0.13)$ & $6.5( \pm 0.06)$ & $6.2( \pm 0.03)$ & $5.9( \pm 0.11)$ \\
\hline TS $(\mathrm{g} / \mathrm{kg})$ & $230( \pm 3.70)$ & $214( \pm 63.7)$ & $309( \pm 101)$ & $311( \pm 1.92)$ & $214( \pm 3.98)$ & $262( \pm 9.69)$ \\
\hline TKN $(\mathrm{g} / \mathrm{kg})$ & $22.3( \pm 0.60)$ & $21.0( \pm 5.76)$ & $30.9( \pm 8.29)$ & $41.2( \pm 4.84)$ & $28.6( \pm 4.64)$ & $36.6( \pm 8.51)$ \\
\hline$P(g / k g)$ & $4.8( \pm 0.37)$ & $4.5( \pm 1.29)$ & $6.9( \pm 2.63)$ & $6.8( \pm 0.40)$ & $5.3( \pm 1.00)$ & $6.3( \pm 2.96)$ \\
\hline $\mathrm{K}(\mathrm{g} / \mathrm{kg})$ & $27.5( \pm 1.43)$ & $24.3( \pm 8.20)$ & $37.4( \pm 9.78)$ & $78.5( \pm 7.46)$ & $53.8( \pm 6.92)$ & $66.9( \pm 11.77)$ \\
\hline
\end{tabular}

the evaporator wall. The incomplete total $\mathrm{NH}_{3}-\mathrm{N}$ condensation should also be taken into account as another possible source of error.

\section{Semi-Continuous Evaporation Tests}

Evaporation Rates. Because the final TS concentration in the semi-continuous evaporation experiments was between 200 increase in batch evaporation experiments with landfill leachate, concluding that a continuous addition of acid was needed to maintain the desired $\mathrm{pH}$. This $\mathrm{pH}$ increase was higher in the experiments performed with digested slurry than in those with fresh slurry. This showed that when using a given initial slurry $\mathrm{pH}$, the $\mathrm{NH}_{3}-\mathrm{N}$ and un-ionized VFA fraction of the two slurry types were different, explaining the differences observed in the percentages of the compounds transferred.

In all cases, $\mathrm{COD} \%$ transferred to the condensate in experiments with fresh slurry was significantly higher than the values obtained with digested slurry (Figure $6 c)$. The different natures of the organic matter of the slurries may explain this fact. Because most of the volatile organic matter is consumed during anaerobic digestion, low biodegradable or non-volatile organic matter mainly composes the COD of the digested slurry.

Concentrate Characterization. One of the objectives of the evaporation treatment is to obtain a concentrate with a higher nutrient concentration than that in the original slurry. The main characteristics of the concentrate are shown in Table 2. Because $\mathrm{P}$ and $\mathrm{K}$ are non-volatile compounds, the resulting concentrate should contain the entire initial $\mathrm{P}$ and $\mathrm{K}$ present in the non-treated slurry. The mass balance performed by applying eq 3 indicated that between 84 and $95 \%$ of the initial $\mathrm{P}$ and between 90 and $97 \%$ of the initial $\mathrm{K}$ were retained in the concentrate. The missing $\mathrm{P}$ and $\mathrm{K}$ could be attributed to experimental error.

Between 83 and $84 \%$ of the initial TKN was retained in the concentrate in experiments with fresh slurry and between 80 and $84 \%$ was retained in those with digested slurry experiments. No relationship was found between the initial slurry $\mathrm{pH}$ and the percent of TKN retained, and no differences were found between the two slurry types. This could be explained by both the small final volume of the concentrate and the observed scaling phenomena in and $250 \mathrm{~g} / \mathrm{kg}$, it can be assumed that the water removed was the free-water fraction, and a constant evaporation rate could therefore be expected. The different characteristics of the slurries tested did not have an important effect on evaporation rates. In the steady-state period, the evaporation rates reported in the fresh slurry experiments were $45.9 \mathrm{~mL}$ condensate/hr, while in the digested slurry experiments it was $43.0 \mathrm{~mL}$ condensate/hr.

Condensate characterization. The evolution of condensate characteristics $\left(\mathrm{NH}_{3}-\mathrm{N}_{\mathrm{T}}\right.$, TVFA, $\mathrm{COD}$, and $\left.\mathrm{pH}\right)$ throughout the semi-continuous experiment are shown in Figure 7. As seen, the studied parameters behaved differently in the two periods. During the transitory period, there were high variations in the composition of the condensate. COD, total $\mathrm{NH}_{3}-\mathrm{N}$ and TVFA concentration increased linearly with the degree of concentration of the slurry. The lowest concentrations were reported after each new addition of slurry, and maximum values were reported just before a new slurry addition (Figure 7). This showed that the degree of slurry concentration also had a major effect on condensate characteristics. ${ }^{8}$ The almost constant condensate characteristics during the steady-state period indicated that a stable running of the system had been achieved (Figure 7).

Steady-state condensate characteristics were compared with those from the batch experiments, with the initial slurry $\mathrm{pH}$ equal to 5 . As expected, the higher evaporation temperature in the semi-continuous experiment (55 ${ }^{\circ} \mathrm{C}$ as opposed to $40{ }^{\circ} \mathrm{C}$ in the batch experiments) lead to higher condensate concentrations of $\mathrm{NH}_{3}-\mathrm{N}$, TVFA, and COD in the semi-continuous (Table 3) than in the batch experiments (Figure 5). Similarly, $\mathrm{NH}_{3}-\mathrm{N}_{\mathrm{T}}$, COD, and TVFA percent transferred to the condensate were larger in the semi-continuous than in the batch experiments (Figure 6).

Comparing the two slurry types, as in batch experiments, VFA \% and COD \% transferred to the condensate were larger for fresh slurry semi-continuous experiments than those for digested slurry. However, $\mathrm{NH}_{3}-\mathrm{N}_{\mathrm{T}}$ $\%$ transferred showed similar values for the two slurry 


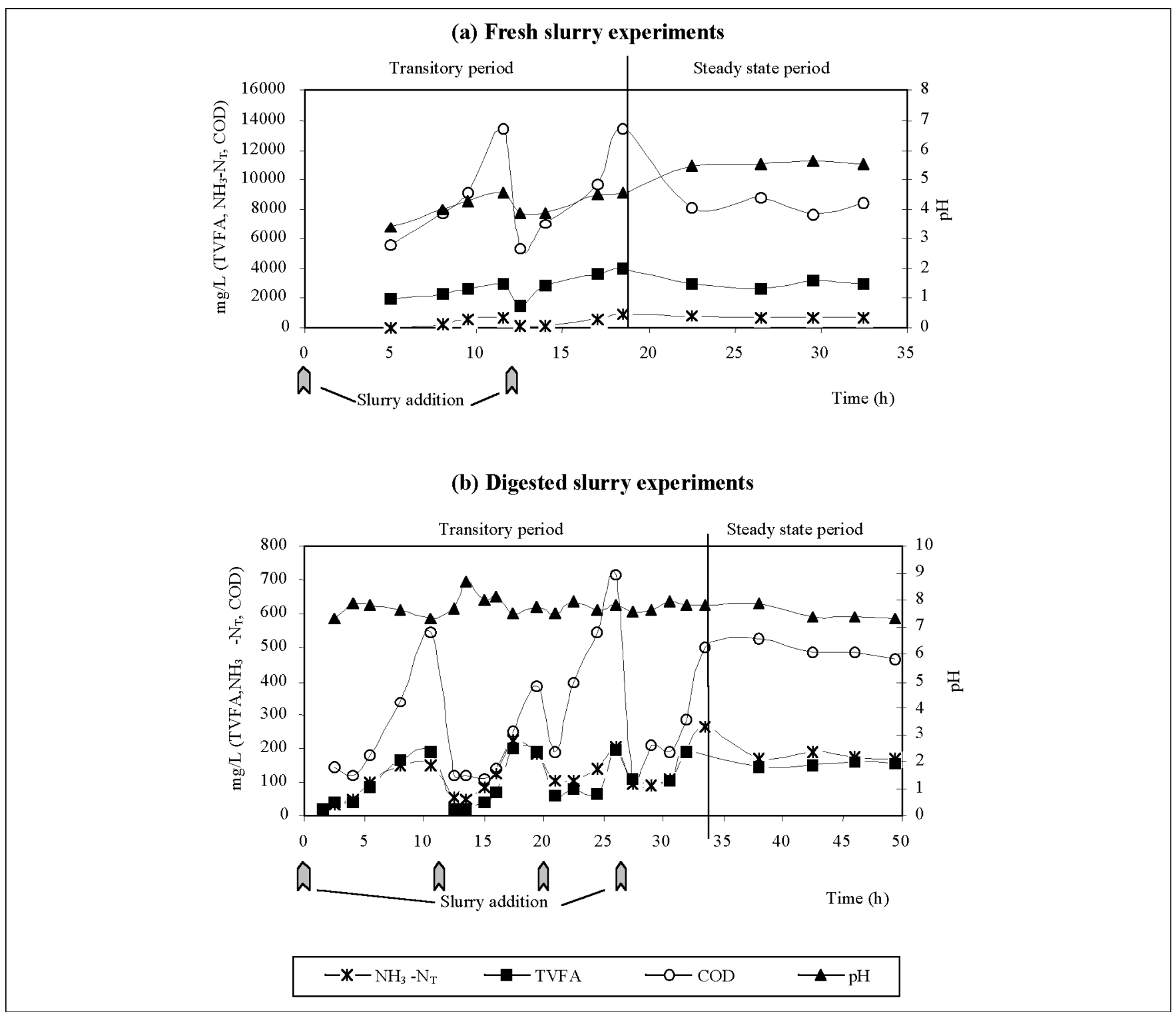

Figure 7. Evolution of condensate characteristics $\left(\mathrm{NH}_{3}-\mathrm{N}_{\mathrm{T}}\right.$, TVFA, $\mathrm{COD}$, and $\left.\mathrm{pH}\right)$ in semi-continuous experiments. In the steady-state period, the slurry was added every $30 \mathrm{~min}$. (a) fresh slurry experiment, (b) digested slurry experiment.

types. The $\mathrm{pH}$ of the condensate also showed a great difference. While the $\mathrm{pH}$ of the condensate from fresh slurry semi-continuous experiments had a $\mathrm{pH}=5.5$, the condensate from digested slurry experiments had a $\mathrm{pH}=7.5$. This was in accordance with the different ammonia and TVFA concentrations of the different condensate samples and showed that the condensate had no buffer capacity.

Table 3. Average concentration (of 4 samples) of total ammonia nitrogen, TVFA, COD, and pH in the steady-state period of the semi-continuous experiment (standard deviations are indicated within brackets).

\begin{tabular}{lcccc}
\hline \hline & $\left.\mathbf{N H}_{\mathbf{3}}-\mathbf{N}_{\mathbf{T}} \mathbf{( m g} / \mathbf{L}\right)$ & TVFA (mg/L) & $\mathbf{C O D}(\mathbf{m g} / \mathbf{L})$ & $\mathbf{p H}$ \\
\hline Fresh Slurry & $679( \pm 73)$ & $2894( \pm 217)$ & $8262( \pm 434)$ & $5.5( \pm 0.1)$ \\
Digested Slurry & $172( \pm 8)$ & $166( \pm 6)$ & $491( \pm 26)$ & $7.5( \pm 0.2)$ \\
\hline \hline
\end{tabular}

To test whether all the volatilized components monitored had been completely recovered in the condensate, the composition of the incondensates samples (vapors condensed outside the vacuum system, 6 in Figure 2) were analyzed. $\mathrm{NH}_{3}-\mathrm{N}_{\mathrm{T}}$, VFA, and COD were detected in the incondensate samples, with similar concentration values as in condensate, showing that it was not possible to recover completely the total $\mathrm{NH}_{3}-\mathrm{N}$, VFA, and COD volatilized through evaporation in the condensate. A supplementary treatment (i.e., biofilter) is therefore needed to achieve a complete control of emissions.

Concentrate Characterization. The characteristics of the concentrate sampled during the steady-state period are shown in Table 4. As seen, the composition of all the 
Table 4. Characteristics of the concentrate in the semi-continuous evaporation experiment

\begin{tabular}{|c|c|c|c|c|c|c|c|c|}
\hline & \multicolumn{4}{|c|}{ Fresh Slurry Concentrate } & \multicolumn{4}{|c|}{ Digested Slurry Concentrate } \\
\hline & Sample 1 & Sample 2 & Sample 3 & Sample 4 & Sample 1 & Sample 2 & Sample 3 & Sample 4 \\
\hline pH & 5.5 & 5.5 & 5.5 & 5.6 & 6.0 & 5.9 & 5.8 & 5.8 \\
\hline TS $(g / k g)$ & 231.6 & 210.5 & 251.4 & 230.6 & 251.3 & 227.9 & 216.1 & 232.2 \\
\hline $\mathrm{NH}_{3}-\mathrm{N}_{\mathrm{T}}(\mathrm{g} / \mathrm{kg})$ & 9.2 & 9.0 & 9.8 & 9.6 & 20.2 & 19.1 & 17.6 & 18.7 \\
\hline $\mathrm{COD}(\mathrm{g} / \mathrm{kg})$ & 202.2 & 226.2 & 219.4 & 214.2 & 141.6 & 132.6 & 128.0 & 139.7 \\
\hline TKN (g/kg) & 20.0 & 18.1 & 22.5 & 18.3 & 25.4 & 23.4 & 22.0 & 24.0 \\
\hline$P(g / k g)$ & 4.6 & 4.5 & 4.5 & 5.3 & 4.5 & 4.4 & 4.1 & 4.2 \\
\hline$K(g / k g)$ & 32.4 & 30.3 & 33.0 & 32.0 & 47.7 & 45.5 & 42.4 & 44.2 \\
\hline
\end{tabular}

samples from the same experiment was quite similar. This was in accordance with the constant characteristics of the condensate reported for the same period (Figure 7).

As in the batch experiments, the final $\mathrm{pH}$ was slightly higher than the initial $\mathrm{pH}$, and it was higher for digested slurry than for fresh slurry. Mass balance calculations (eq 3 ) showed that $98.8 \%$ of the initial $\mathrm{K}$ and 95.4\% of the initial $\mathrm{P}$ were retained in the fresh slurry concentrate. Almost all of the K (98.2\%) and $94.5 \%$ of the initial $\mathrm{P}$ were found in the digested slurry concentrate.

The retained TKN \% was $86 \%$ in the fresh slurry concentrate and $81 \%$ in the digested slurry. On the contrary, the percent $\mathrm{NH}_{3}-\mathrm{N}_{\mathrm{T}}$ retained was $80.7 \%$ for the fresh slurry concentrate and $86.6 \%$ for the digested slurry concentrate. The COD \% retained was 86.3 and $91.9 \%$, respectively. This confirmed that not all the $\mathrm{NH}_{3}-\mathrm{N}$ and $\mathrm{COD}$ was recovered in the condensate. However, there could have been a relatively large experimental error when calculating these figures. As in the batch experiments, scaling phenomena were observed, and therefore the measurement of the final amount of concentrate was not completely accurate. Small errors in the weight of the concentrate could result in large errors in the subsequent calculations of the global mass balance, because of its extremely high concentration.

\section{CONCLUSIONS}

The characteristics $\left(\mathrm{NH}_{3}-\mathrm{N}_{\mathrm{T}}\right.$, TVFA, and COD) of the condensate obtained through batch evaporation experiments of pig slurry liquid fraction were strongly dependent on the initial slurry $\mathrm{pH}$. As expected, the lower the initial slurry $\mathrm{pH}$, the lower the $\mathrm{NH}_{3}-\mathrm{N}$ concentration in the condensate; and the lower the initial slurry $\mathrm{pH}$, the higher the TVFA concentration in the condensate. However, the COD in the condensate behaved differently depending on the pig slurry type. In the fresh slurry experiments, COD followed the same pattern as TVFA, while in the digested slurry experiments, COD did not have any relation with the initial slurry $\mathrm{pH}$, showing a very low transfer rate. The percentages of COD and TVFA transferred to the condensate were lower for the digested slurry than for the fresh slurry, while the percentage of $\mathrm{NH}_{3}-\mathrm{N}_{\mathrm{T}}$ transferred has shown the opposite behavior. It can be concluded that under these operational conditions $\left(\mathrm{T}=40^{\circ} \mathrm{C}, \mathrm{P}=6.7\right.$ $\mathrm{kPa}$ ) and within the range of $\mathrm{pH}$ values studied, a onestage evaporation treatment would be sufficient to obtain high-quality condensates when treating digested slurry.

Semi-continuous experiments showed that the treatment temperature/pressure and the degree of concentration of the slurry are also important factors to be considered with regard to condensate composition. In this case, because of the operational temperature used $\left(55^{\circ} \mathrm{C}\right)$, higher concentrations of the studied compounds than in batch experiments were reported, but they followed the same transfer pattern.

Evaporation appears to be an interesting option for pig slurry treatment in areas with a structural nutrient surplus, facilitating transport and nutrient recovery. In addition to providing part of the required thermal energy, previous anaerobic digestion of the slurry presents clear advantages for the concentration/evaporation process. The consumption of organic matter during anaerobic digestion reduces its volatilization during evaporation and therefore leads to significantly higher quality condensates.

\section{ACKNOWLEDGMENTS}

This work was supported by a grant from CIRIT (Research Council of the Government of Catalonia) and by research contract CTT-C253 with SGT SA. We acknowledge M.R. Teira-Esmatges for her useful comments.

\section{REFERENCES}

1. Beck, J.; Burton, C.H. Manure Techniques in Europe-Results of an EUConcerted Action. AgEng Oslo. International Conference on Agricultural Engineering; 1998; p 11. 
2. Manure Management. Treatment Strategies for Sustainable Agriculture, Burton, C.H., Ed.; Silsoe Reserach Institute: Bedford, UK, 1997; p 181.

3. Perry, R.H. Perry. Manual del ingeniero químico, 6th ed., McGrawHill: 1992; Vol. 1.

4. Lide. CRC Handbook of Chemistry and Physics, 73rd ed., CRC Press: 1993.

5. Marks, A.L.; Luthy, R.G.; Diweker, U.M. Semi-Continuous Evaporation Model for Leachate Treatment Process Evaluation; Environ. Prog. 1994, 13 (4), 278-289.

6. Vitolo, S.; Petarca, L.; Bresci, B. Treatment of Olive Oil Industry Wastes; Biores. Technol. 1999, 67, 129-137.

7. Nilsson, B.; Strand, O. Evaporator Condensate and Caustic Extraction Liquor from a Pulp Factory Treated with an Anaerobic Process; Wat. Sci. Tech. 1994, 29 (5-6), 399-407.

8. McKeough, P.; Fagernäs, L. Further Evaporation and Final Treatment of Process-Water Concentrates; Wat. Sci. Tech. 1999, 40 (1112), 25-32.

9. Birchler, D.R.; Milke, M.W.; Marks, A.L.; Luthy, R.G. Landfill Leachate Treatment by Evaporation; J. Environ. Eng. 1994, 120 (5), 1109-1131.

10. Grüter, H.; Matter, M.; Oehlmann, K.H.; Hicks, M.D. Drying of Sewage Sludge-An Important Step in Waste Disposal; Wat. Sci. Tech. 1990, 22 (12), 57-63.

11. Lowe, P. Developments in the Thermal Drying of Sewage Sludge; JCIWEM 1995, 9 (3), 306-316.

12. Have, P.J.W.; Chiappini, U. Processing of Manure Surpluses. In European Conference. Environment Agriculture Stock Farming in Europe, Mantova, Italy, 1993; p 29.

13. Standard Methods for the Examination of Water and Wastewater, 19th ed. APHA, AWWA, WEF: Washington, DC, 1995.
14. Iza, J. Control del proceso anaerobio. In $1 r$ Curs d'Enginyeria Ambiental. Tractament anaerobi d'aigües residuals i residus de forta càrrega: paràmetres de dissen $i$ tecnologies en ús, Paperkite ed.; Flotats, X., Ed.; Lleida, Spain, 1995; pp. 175-202.

15. SAS/STAT User'S Guide; Version 6; 4th ed.; SAS Institute: Cary, NC, 1989.

16. Hill, D.T. Alkalinity Measurements in Anaerobic Digestion Systems as Influenced by Organic Acid Level and Endpoint pH; Trans. ASAE 1990; 33 (5), 1717-1719.

17. Hill, D.T.; Jenkins, S.R. Measuring Alkalinity Accurately in Aqueous Systems Containing High Organic Acid Concentrations; Trans. ASAE 1989; 32 (6), 2175-2178.

18. Huercio, A.; Varas, F.J.; Espuña, A.; Puigjaner, L.; Herranz, J. Applied Adaptative Dynamical Identification to the Prediction of Chemical Process Evolutions; Periodica Polytech. Ser. Chem. Eng. 1994, 38 (1-2), 81-92.

\section{About the Authors}

August Bonmatí received his Ph.D. from the University of Lleida, and is now an assistant professor in the Chemical Engineering Department, University of Girona. Xavier Flotats (corresponding author; phone: 34 973702603; fax: 34 973702613; e-mail: flotats@macs.udl.es) is an associate professor in Environmental Engineering at the Department of Environment and Soil Science, University of Lleida. 